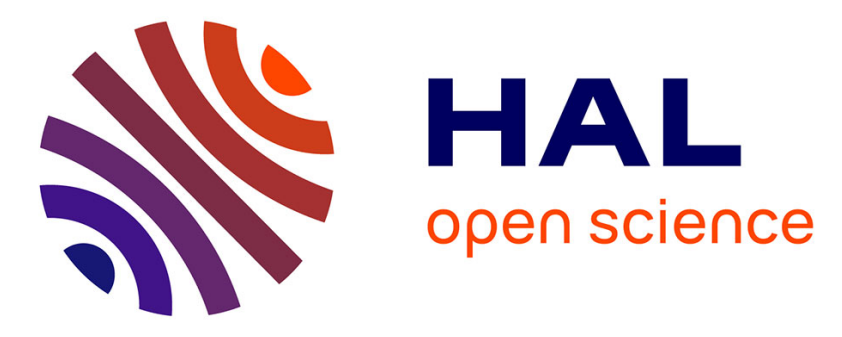

\title{
Syndepositional glauconite as a paleoenvironmental proxy - the lower Cenomanian Chalk of Cap Blanc Nez (N-France)
}

Nicolas Tribovillard, Viviane Bout-roumazeilles, Marion Delattre, Sandra Ventalon, Romain Abraham, Oussenatou Nzié

\section{To cite this version:}

Nicolas Tribovillard, Viviane Bout-roumazeilles, Marion Delattre, Sandra Ventalon, Romain Abraham, et al.. Syndepositional glauconite as a paleoenvironmental proxy - the lower Cenomanian Chalk of Cap Blanc Nez (N-France). Chemical Geology, 2021, 584, pp.120508. 10.1016/j.chemgeo.2021.120508. hal-03374316

\author{
HAL Id: hal-03374316 \\ https://hal.science/hal-03374316
}

Submitted on 12 Oct 2021

HAL is a multi-disciplinary open access archive for the deposit and dissemination of scientific research documents, whether they are published or not. The documents may come from teaching and research institutions in France or abroad, or from public or private research centers.
L'archive ouverte pluridisciplinaire $\mathbf{H A L}$, est destinée au dépôt et à la diffusion de documents scientifiques de niveau recherche, publiés ou non, émanant des établissements d'enseignement et de recherche français ou étrangers, des laboratoires publics ou privés. 


\section{Revised Version R2}

Syndepositional glauconite as a paleoenvironmental proxy - the Lower Cenomanian Chalk of Cap Blanc Nez (N-France)

Nicolas Tribovillard ${ }^{1 *}$, Viviane Bout-Roumazeilles ${ }^{1}$, Marion Delattre ${ }^{1}$, Sandra Ventalon ${ }^{1}$, Romain Abraham ${ }^{1}$, Oussenatou Nzié ${ }^{1}$

${ }^{1}$ Univ. Lille, CNRS, Univ. Littoral Côte d'Opale, UMR 8187 LOG - Laboratoire d'Océanologie et de Géosciences, F-59000 Lille, France

* nicolas.tribovillard@univ-lille.fr

Keywords: Germanium, Ge/Si ratio, redox conditions, sedimentation rate, organic matter

Abstract. - At Cap Blanc Nez (Channel coast, France), the chalk of the Lower Cenomanian is very rich in glauconite. Glauconite is of authigenic origin and requires the mobilization of chemical elements for its growth: $\mathrm{Si}, \mathrm{Fe}$ and $\mathrm{K}$. If we already know thanks to elementary geochemistry ( $\mathrm{Ge} / \mathrm{Si}$ ratio) that the silica of the flint present in the chalk originates from the dissolution of sponges, is it the same for glauconite? This question only makes sense if glauconite is proved to be autochthonous and synsedimentary, and not reworked during the Cenomanian transgression. In addition, we wanted to know whether the study of the content of trace elements in glauconite could provide information on the conditions of authigenesis in glauconious chalk.

The clay content of the chalk from the Lower Cenomanian has been examined and the green minerals were extracted from the rock to study their morphology, mineralogy, geochemistry (major \& trace elements ) and grain size. The chalk consists of calcium carbonate, smectite and true glauconite, in the form of pellets, sometimes with rare traces of quartz and some centimeter-scale phosphate gravel. The grain-size distribution of the glauconites varies from one sample to another and is always poorly sorted, which militates in favor of an autochthonous (not reworked) origin of these minerals. This origin is also suggested by the virtual absence of terrigenous minerals, except for smectite known for its potential for wide distribution in the marine environment. The geochemistry of the samples shows a very homogeneous composition of major and trace elements, with a $\mathrm{K}_{2} \mathrm{O}$ content greater than $8 \%$. This characterizes these glauconites as being very evolved, which indicates a long authigenic formation time (>100 ky) and therefore an extremely reduced or irregular sedimentation rate. Here, glauconites are very rich in germanium, which makes it impossible to identify a source of silica (unlike what is possible with flints). It cannot therefore be said that the silica results from the dissolution of sponges but this enrichment in Ge, coupled with that in vanadium and the absence of enrichment in molybdenum, indicates a slightly reducing deposition milieu (suboxic). Such conditions usually favor organic matter accumulation, but not here, due to protracted sedimentation hiatuses. Lastly, glauconite trapped relatively large amounts of Ge due to reducing conditions and long exposure time to seawater, which makes it 
a potential chronometer assessing the duration of authigenesis, and a possible compartment of the marine cycle of germanium.

\section{Introduction}

The Boulonnais coastline (English Chanel, Northernmost France; Fig. 1) exhibits chalk cliffs of Cenomanian to Santonian age. At Cap Blanc Nez, the base of the cliff yields a few meters of glauconious chalk (Fig. 2). In addition, the chalk does not show abundant flint concretions in the lower part of the cliff but their abundance increases upward. Both glauconite and flint are authigenic minerals and their growth requires the availability and mobilization of chemical elements, notably silicium in the form of silica, plus iron and potassium, regarding glauconite. The silica of the flint has been proved to be derived from sponges dwelling on the sea bottom during chalk deposition; the (partial) dissolution of the sponges fueled the diagenetic growth of the flint (Tribovillard et al., 2013). The present paper focuses on the glauconite present in large abundance at the base of the Cenomanian chalk. The first question is whether glauconite formed in situ or was reworked from older deposits and concentrated in the basal chalk. If glauconite was autochthonous and synsedimentary, then it may be wondered whether the silica required for abundant glauconite to form also derived from sponge dissolution, as for flints. If glauconite and flints share in common a sponge-derived silica, why do they seem to be mutually exclusive? Lastly, can the trace-element composition of glauconite tell us something about the paleo-redox conditions of its authigenesis? Could glauconite be a trap for some trace elements?

To address these questions, we examined the basal part of the Cenomanian chalk at Cap Blanc Nez because the glauconite there has been diagnosed as autochthonous (Amorosi and Centineo, 2000; see below). The glauconite grains were extracted from the chalk and examined through scanning electron microscope, their grain-size distribution and their chemical composition (major and trace elements) were investigated, as well as their mineralogy and that of the clay-mineral assemblage of the rocks.

\section{Geological background}

\subsection{Glauconite}

Glauconite (first defined by Odin and Letolle, 1980), corresponds to (marine) green sediments formed by mixed-layer glauconite-smectite minerals, differing from the non-expanding glauconitic mica or true glauconite (see details in Odin and Matter, 1981; Chamley, 2001; Velde, 2014; López-Quirós et al., 2019). Glauconite is an iron-potassium hydrous phyllosilicate that is considered to be of diagenetic origin (Odin and Matter, 1980; López-Quirós et al., 2020). Various factors have been put forward to account for glauconite formation: reduced sedimentation rates, protracted availability of (dissolved) cations, oxygen-depleted, mildly reducing, conditions for the main ones (Odin and Matter, 1981; Amorosi, 1995; El Albani et al., 2005; Meunier and El Albani, 2007; Banerjee et al., 2016a, 2016b; Huggett, 2021; Roy Choudhury et al., 2021). In addition, glauconite is often present in the form of pellets or lobate grains, showing frequent surface cracks (Boyer et al., 1977; Bayliss and Syvitski, 1982; Amorosi and Centineo, 2000; Adriaens et al., 2014; Velde, 2014). Lastly, glauconite is often used as a tool for reconstructing sea-level variations (e.g., Banerjee et al., 2008, 2016; Hesselbo and Huggett, 2001; Huggett et al. 2017). 


\subsection{The chalk at Cap Blanc Nez}

The Lower Cenomanian, carbonate dominated, deposits of Cap Blanc Nez are separated from the underlying Albian Clays of the Saint Pô Formation (Fm.) by a thin level (ca. 10-20 cm) of grey marly clay containing abundant glauconite and phosphatic pebbles (the so-called Lottinghen Fm.; Amedro and Robaszynski, 1999). The lower Cenomanian can be divided into two formations: the Strouanne Fm., also termed "Tourtia", underlaying the Petit Blanc Nez Fm. Glauconite is abundant in the marly chalks of the Strouanne Fm. (2 m thick at Cap Blanc Nez), where three depositional cycles may be defined (Robaszynski and Amedro, 1993). The cycles are made of dark-green, almost black, levels overlain by grey levels (the color is due to the presence of glauconite) and are bounded by burrowed surfaces showing fossil sponges. In the Boulonnais area, the condensed hemipelagic deposits of the Lower Cenomanian may be characterized by depositional cycles yielding contrasted abundances of glauconite (Amedro, 1994; Amedro and Robaszynski, 1999; Amorosi and Centineo, 2000). As often, the abundance of glauconite was used by these authors to establish a sequence stratigraphy framework. According to Amorosi and Centineo (2000), a clear distinction may be observed between the abundant, autochthonous (formed in situ), highly evolved, glauconite of the Strouanne Fm. from one part, and the scarce, allochthonous (reworked), less evolved, glauconite of the overlying Petit Blanc Nez Fm. This result made us chose to examine the glauconite of the Strouanne Fm.

\section{Materials and methods}

Four samples of chalk, termed from 1 to 4 , weighing between 1.0 and $1.5 \mathrm{~kg}$ each, were picked out of the base of the Strouanne Fm. Their color is varied due to the abundance of dark-green to black glauconitic grains (Fig. 3). The grains are visible to the naked eye.

The clay minerals contained in the chalk samples were determined by $\mathrm{x}$-ray diffraction according to the standard protocol described in Bout-Roumazeilles et al. (1999). The glauconite grains were isolated as follows. Samples of $100 \mathrm{~g}$ of glauconious chalk were attacked with $\mathrm{HCl}$ to dissolve the carbonates before being rinsed. Several rinses were carried out leaving sufficient time for minerals heavier than clay minerals to settle and for clays to be removed with the supernatant. This operation was repeated about 25 times, until the liquid remained clear. All that remained in the beaker were the grains of glauconite, some rare phosphate debris, and, in the case of sample 2, few grains of quartz. Once the phosphate debris had been removed by hand, the dry sample was reweighed, which made it possible to estimate the proportion by weight of glauconite in the chalks studied. Quartz was therefore included in the weighing for sample 2, but it only represents very small quantities.

The glauconite grains were observed with a scanning electron microscope (SEM) equipped with an analytical probe of the EDS type. They were also analyzed by x-ray diffraction (XRD) to determine the mineralogy of the grains. This analysis was carried out in two ways, the one conventionally used to analyze the composition of clay mineral assemblages (oriented mounts) and the one used to study non-oriented powders called bulk rock. This second technique was implemented to test whether glauconite could be confused with illite in conventional analyzes of clay minerals by XRD by focusing on the 002 peak (at $5 \AA$ ), the reflection of 
which is much weaker for glauconite than for illite. Furthermore, the analysis of the grain size of the glauconite particles was carried out with an analyzer equipped with a laser beam (Malvern MasterSizer; protocol in Trentesaux et al., 2001). These different analyzes were carried out at the LOG laboratory at the University of Lille. Finally, the glauconite grains were analyzed at the CNRS Rock and Mineral Analysis Service (SARM), in Vandoeuvre-les-Nancy (France) so that the elemental chemical composition (major and traces) could be determined. Full details of the analytical protocol (ICP-OES and ICP-MS) can be found in Carignan et al. (2002).

\section{Results}

The binocular and SEM observation of the green grains extracted from the chalks shows particles in the form of pellets (Fig. 4). These pellets generally show cracks. Punctual EDS analysis of some pellets yields homogeneous values for major-element content $(\mathrm{Mg}, \mathrm{Al}, \mathrm{Si}, \mathrm{K} \& \mathrm{Fe}$ ) as illustrated with Table 1 (note that these analyses are only semi-quantitative and see below for classic analytical results).

Analysis by XRD (non-oriented powder) of the fraction free of carbonates and clay minerals only shows glauconite sensu stricto in samples $1,3 \& 4$. Sample 2 also contains traces of quartz (Fig. 5). Analysis by XRD (non-oriented powder) of the green supernatant recovered at the end of the particle size analysis only shows glauconite. The analysis of the assemblage of clay minerals (oriented aggregates, a.k.a. oriented mounts) shows iron smectite and illite but the analysis of the size fraction $<2 \mu \mathrm{m}$ using non-oriented powder shows that what could be taken for illite is actually glauconite (based on the 002 reflection intensity). In conclusion, the decarbonated fraction of the four chalk samples contains iron smectite and glauconite, sample 2 also contains traces of quartz (Fig. 5).

The size distribution of the glauconite grains is different for each of the samples studied (Fig. 5). In addition, each sample shows a very irregular distribution (Fig. 5). The analysis revealed an abundant fraction of size $<1-2 \mu \mathrm{m}$. As stated above, this fraction, when recovered, was found to be glauconite. It therefore seems that these very small particles were detached from the glauconitic pellets by mechanical effect: a wear of the grains in the water flow which moves the particles during the grain-size analysis.

The geochemical analyses (ICP-OES and ICP-MS) of the four samples of glauconite show tight results for each of the major elements and also for the trace elements (Table 2 and Appendix Table S1). With regard to the major elements, the concentrations are even tighter than they are with the EDS analyzes. In particular, with regard to the element always taken into account in the study of glauconite, the $\mathrm{K}_{2} \mathrm{O}$ content fluctuates between $8.19 \%$ and $8.48 \%$. The potassium content allows the degree of maturity of glauconite to be estimated among nascent, slightly evolved, evolved and highly evolved, according to Odin and Matter (1981). Here, the glauconite is highly evolved.

Regarding redox-sensitive trace elements, the analyses listed in Table 2 show the noticeable presence of vanadium (V; 92.0-95.8 $\mu \mathrm{g} / \mathrm{g}$ ) but molybdenum (Mo) is below the analytical detection threshold and uranium $(\mathrm{U})$ concentration is quite low $(0.09-0.15 \mu \mathrm{g} / \mathrm{g})$. Interpreting trace element concentrations measured on authigenic minerals such as glauconite can be tricky. The normalization which is conventionally and very conveniently done using the average values of crustal abundances makes little sense here because glauconite 
will see its composition be influenced by the abundances of trace elements in seawater, or even their residence time in the marine environment. The three elements sensitive to redox conditions, Mo, $\mathrm{U}$ and $\mathrm{V}$, are present in seawater in relatively close concentrations: $10 \mu \mathrm{g} / \mathrm{g}, 3.2 \mu \mathrm{g} / \mathrm{g}$ and $2 \mu \mathrm{g} / \mathrm{g}$, respectively. However, by comparing the contents of the glauconite studied and those of seawater, we observe that, in the glauconite, Mo is absent, $\mathrm{U}$ is depleted, and finally, $\mathrm{V}$ is enriched compared to seawater of a factor close to $\mathrm{x} 47$.

Germanium (Ge), which is also an element sensitive to redox conditions (Tribovillard et al., 2011), is weakly present in seawater $(0.0055 \mu \mathrm{g} / \mathrm{g})$ but it is highly enriched in the glauconite of this study (x900). Germanium being an element possibly substituting for silicium, it might be instructive to compare the $\mathrm{Ge} / \mathrm{SiO}_{2}$ ratios of seawater and glauconite. The $\mathrm{Ge} / \mathrm{SiO}_{2}$ ratio of seawater is 0.02 (with $\mathrm{Ge}$ in $\mathrm{ppm}$ or $\mu \mathrm{g} / \mathrm{g}$ and $\mathrm{SiO}_{2}$ in $\%)$ and the ratio for glauconite is between 0.09 and 0.10 (with the same units). In other words, the enrichment factor of glauconite relative to seawater is about x5 (in the range 4.61-5.09).

\section{Discussion}

\subsection{Glauconite formed authigenically during chalk deposition}

The mineralogical composition of the chalks studied here is quite simple: carbonates, glauconite and iron smectite (plus traces of quartz in one sample and rare phosphatic debris). Smectite, due to its high buoyancy, is able to disperse widely in seas, its dispersal power is higher that that of the other clay minerals (Chamley, 1989). In the Boulonnais, the Mesozoic deposits systematically contain smectite (Deconinck et al., 1989). The fact that smectite (plus traces of quartz) is the only detrital element observed strongly suggests that the clastic supply, either reworked or land-derived directly, was minimal in the lower Cenomanian chalk. In addition, the glauconite show a grain-size distribution characterized by poor sorting and variable sizes. This observation indicates that the glauconite were not sorted by the hydrodynamic energy of the depositional milieu, but, instead, they developed within the sediment or at the sediment-water interface. The autochthonous, syndepositional, origin of the glauconite is also confirmed by the deep cracks observed on the pellets (see discussion of this criterion in Odin and Matter, 1981). Thus, our results meet those of Amorosi and Centineo (2000) about the autochthonous nature of the glauconite of the Lower Cenomanian at Cap Blanc Nez.

\subsection{The origin of the silica}

Now that it may be considered that glauconite formed authigenically during chalk deposition, the question of the origin of the silica involved in its growth may be addressed. Tribovillard et al. (2013) demonstrated that the silica involved in the flint of the Cap Blanc Nez chalk was originating from sponges being (partly) dissolved postmortem. Could this also apply to authigenic glauconite? The conclusions of Tribovillard et al. (2013) were based on the values of the Ge/Si ratio, being similar for fossil sponges and flints in the case of the Cap Blanc Nez chalk. Here, the glauconite analyses yield a Ge/Si of ca. 20x10-6 , being much larger than any value classically reported for sedimentary objects. Nevertheless, the values observed in the present study match those of a Cenomanian glauconite (95 Ma) from Normandy, analyzed by Govindaraju (1994; see also 
Kapusta et al.,1997). Thus, our results are not anomalous, but the high values of Ge/Si prevent us from identifying any possible source of silica and it cannot be evidenced this way that sponges dissolution fueled glauconite authigenesis, how tempting this hypothesis may be.

\subsection{Redox conditions of authigenesis}

Germanium has also be proven to be sensitive to redox conditions (Tribovillard et al., 2011 and references therein). Therefore, its enrichment in glauconite could result from the reducing conditions required for glauconite growth. Glauconite, possibly bearing $\mathrm{Fe}^{2+}$ and $\mathrm{Fe}^{3+}$, is commonly known to form under mildly reducing conditions (see above). Consequently, an enrichment in redox-sensitive trace elements may be expected in glauconite grains, being micro-sites of capture of dissolved elements during their authigenic growth. The substitution of Ge for Si (e.g., Rouxel et al., 2006) would thus be favored under reducing conditions, ending with the high Ge/Si ratio values observed. To the best of our knowledge, this is the first report that the substitution of Si by Ge would be controlled by redox conditions in glauconite. Moreover, we could not find papers yielding Ge concentrations of glauconite other than those mentioned here. Therefore, the results presented here open up future path of investigation, regarding the relationships between redox conditions and Ge concentration in authigenic, synsedimentary glauconite.

In the same way, vanadium is known to be sensitive to reducing conditions and to be incorporated into authigenic minerals (especially phyllosilicates) in a reduced form (Breit and Wanty, 1991; Wanty and Goldhaber, 1992; Tribovillard et al., 2006; Meunier, 1994; Huang et al., 2015; Gustafsson, 2019). Therefore, the enrichment in $\mathrm{V}$ observed here is consistent with the redox conditions favoring glauconitization. Although mildly reducing conditions are required for its authigenic formation, the glauconite studied is not enriched in Mo and U, two redox proxies present in the dissolved state in seawater. Molybdenum is not detected in our samples and $\mathrm{U}$ is hardly observable. Uranium reduction, under mildly reducing conditions, from U(VI) to U(IV) occurs under redox conditions such as those of reduction of Fe(III) to Fe(II) in normal seawater, and its enrichment in glauconite could be expected. With its large atomic radius, uranium is known to adsorb easily onto clay minerals but not to be incorporated into them (e.g., Chamley, 1989). Here, the glauconite analyzed have been extracted from the chalk using $\mathrm{HCl}$, which must have desorbed any surface-attached chemical species, and, since authigenic phyllosilicates do not incorporate $U$ in their lattice, the quasi-absence of $U$ is logical, despite the redox context.

Molybdenum is a redox sensitive element but, in reducing environments, its transfer from the water column to the sediments is stimulated under strongly reducing, euxinic, conditions, helped by the presence of organic-matter fluxes (Tribovillard, 2006; Dahl et al., 2016; Helz and Vorlicek, 2019; Bennett and Canfield, 2020). Such conditions were not met during the deposition of the Lower Cenomanian at Cap Blanc Nez. The absence of pyrite is revealing: there was no competition between the respective formations of glauconite and pyrite, as far as the reactive iron availability is concerned. Iron was present, as evidenced by its presence in glauconite, but bacterially mediated sulfate reduction was not operating at the place where authigenic growth took place. The depositional conditions prevailing at the sediment-water interface, or close to it, were prone to the reduction of iron species or to denitrification but not to sulfate reduction. The latter must have developed 
(if ever) at some distance below the sediment-water interface (see below). To conclude with molybdenum, the absence of sulfide and organic matter in the zone of authigenic glauconite growth precluded any enrichment in this element.

The results presented here are consistent with the results of Franus et al. (2010), also mentioning the notable presence of vanadium, together with the absence of $U$ and Mo, in the glauconite sample they studied. Again, as the examination of the $\mathrm{V}$ content of glauconite is hardly mentioned in the literature, our findings pave the way for future developments, as far as the redox conditions of glauconite authigenesis are concerned.

\subsection{Sedimentation rate}

The so-called maturity of glauconite pellets discussed by Odin and Matter (1981) is based on morphological and chemical characteristics of the pellets (see also Chamley, 1989). The maturity, distinguished among nascent, slightly evolved, evolved and highly evolved, is related to the time its authigenic growth lasted. Here, with $\mathrm{K}_{2} \mathrm{O}$ exceeding $8 \%$ of the glauconite composition, the mineral can be said to be highly evolved, which implies that its evolution must have lasted between $100 \mathrm{ky}$ and 1 My (Odin and Matter, 1981). With such protracted hiatuses, the sedimentation rate cannot be determined satisfactorily. It may only be stated that the sedimentation must have been extremely low at times. Only a mean rate can be calculated: taking into account the $68 \mathrm{~m}$ of thickness of the Cenomanian deposits and the 6.6 My of duration for the Cenomanian, according to the 2021 version of the Chronostratigraphic Chart, the average sedimentation rate was close to $1 \mathrm{~cm} / \mathrm{ky}$. Such low values for the sedimentation rate and protracted hiatuses are to be related with the depositional environment of the Cenomanian chalk. As discussed by Deconinck et al. (1989), Deconinck and Chamley (1995) and Amorosi and Centineo (2000), the transgressive context of the (Lower) Cenomanian induced the development of extended epicontinental seas, pushing emerged lands farther and farther. As a consequence, the landderived supply decreased to minimal values, with only smectite being able to drift to the Cap Blanc Nez location. Similarly, the epicontinental seas may have suffered from a lack of land-derived nutrients and the seas must have turned to oligotrophic conditions, as evidenced by the quasi-exclusive presence of coccolithophorids (e.g., Jordan and Chamberlain, 1997; Litchman, 2007). To conclude, rising sea level, lowered classic supply and reduced productivity would have contributed to the decrease in the sedimentation rate.

\subsection{Implications for organic matter accumulation}

The examination of the glauconite in the Lower Cenomanian chalk allowed us to determine that redox conditions were moderately reducing at the sediment-water interface or at shallow depth below it, and that the sedimentation rate was at zero for protracted periods of time. Such redox conditions coupled to slow sedimentation are commonly considered to be factors favoring organic matter preservation (anoxic conditions) and concentration (no dilution by inorganic phases), as discussed in, e.g., Tyson (1995, 2005), Sageman et al. (2003), Bohacs et al. (2005), Katz (2005), Burdige (2006). Here in spite of the presence of the favorable factors, the chalk is devoid of organic matter. This absence may be ascribed to the long time organic matter was exposed to seawater and benthic life at the sediment-water interface (or close to it). Organic matter decay must 
have favored the development of reducing conditions through $\mathrm{O}_{2}$ consumption, but organic matter remineralization was complete before burial. This situation illustrates well that a low sedimentation rate, though usually favoring organic matter accumulation, reaches the limits of its power when its value is too low, as was the case for the chalk studied here.

The organic matter decay may have had another role. Organic matter remineralization releases $\mathrm{CO}_{2}$, lowering the $\mathrm{pH}$. This acidity may cause some minerals (carbonates or silicates) to be leached, possibly releasing $\mathrm{K}^{+}$ions in the pore water. The incorporation of $\mathrm{K}^{+}$into smectites may help them to evolve toward glauconite during diagenesis/authigenesis (Meunier and El Albani, 2007).

In addition, this chalk is devoid of pyrite, which indicates that the sulfate reduction step of the diagenetic sequence had not been reached and/or that reactive iron was absent, during authigenesis. Because synsedimentary glauconite is observed, iron was present. However, the iron involved in the glauconite growth was probably not available in a solubilized form in the seawater, but it must have been hosted by iron smectites. Iron smectite is a reputed support for glauconitization in pellets (Bayliss and Syvitski, 1982; Chamley, 1989; Assale et al., 2020; López-Quirós et al., 2020). The absence of reactive iron could have favored organic matter sulfurization, a factor propitious to organic matter preservation (synthesis in Tribovillard et al., 2015 and references therein). However, the absence of molybdenum in the glauconite studied strongly suggests that sulfide ions were absent during glauconitization, therefore, sulfate reduction did not operate during this diagenetic step. This is consistent with the common view considering that glauconite forms under mildly reducing conditions (see above).

\subsection{Oceanic germanium budget: a possible impact?}

The glauconite grains examined here are highly evolved: they benefited from protracted periods of time allowing germanium to be captured from seawater during authigenesis. This capture was favored by moderately reducing conditions. As a consequence, the Ge/Si ratio of these glauconite grains is much higher than that commonly measured on rocks or sediment-forming particles (Rouxel et al., 2006; Tribovillard et al., 2013; Guillermic et al., 2017). Glauconite is a rather common mineral, usually present in marine environments and possibly concentrated during periods of transgression. For instance, the glauconite of the Cap Blanc Nez is contemporary with that of the chalk of Kent (Amédro and Robaszynski, 1999), which represents quite a lot of glauconite, therefore, of germanium immobilized during a specific time slice. On a larger scale, the transgressive facies of the Cenomanian worldwide or of any age represents possible traps of Ge.The amount of Ge incorporated into such traps could be related to the duration of the exchanges with seawater (that is, the degree of maturity of glauconite). As an opening for possible research developments on the Ge cycle that is still partly constrained (Sutton et al., 2010; Guillermic et al., 2017), several questions could be tackled: could periods of formation of significant amounts of glauconite (or, on a larger scale, of the green mineral family) affect the Ge inventory of the ocean? Is there an isotope fractionation of Ge between seawater and glauconite? Could it impact the isotope composition of Ge in seawater?

\section{Conclusion}


The examination of the glauconite of the Lower Cenomanian chalk at Cap Blanc Nez is informative. The formation of glauconite was autochthonous and synsedimentary, which allows it to be used as a paleoenvironmental proxy. Its morphology and $\mathrm{K}_{2} \mathrm{O}$ content indicate a long time of growth and evolution $\left(10^{5} \mathrm{y}\right.$ to $10^{6}$ y), in turn indicating a sedimentation characterized by protracted hiatuses. This slow sedimentation may be accounted for by the conjunction of various factors: rising sea level, low terrigenous supply (remote and already eroded emerged lands) and low productivity. These factors are intertwined, resulting from the large Cenomanian transgression worldwide acting as the driving force. The slow sedimentation maintained long times of exchanges between seawater and authigenic minerals (glauconite) growing at (close to) the sedimentwater interface. The vanadium concentrations of glauconite testifies to the reducing conditions that prevailed during authigenesis. These reducing conditions induced the enrichment of glauconite in germanium, a littleknown redox tracer. This enrichment precluded using the Ge/Si ratio to identify the source of the silica involved in the glauconite growth but it suggests that the Ge/Si ratio could echo the duration of authigenesis. In the same way, the redox-controlled incorporation of $\mathrm{V}$ could be depending of the duration of the authigenic formation of glauconite. Ge/Si and V content of glauconite as a possible chronometer for authigenesis ? A Ge and $\mathrm{V}$ incorporation correlated with the seawater-exposure time? These hypotheses constitute a new avenue of research concerning the conditions of formation of synsedimentary glauconite. Such hypotheses should be tested on glauconite of various degrees of maturity. Lastly, authigenic silicate such as glauconite could represent an unsuspected compartment of the Ge cycle.

Acknowledgements. Thanks to the Programme Tellus Syster of the French Institut des Sciences de l'Univers (INSU) for funding our work, and to the Earth Science Department of Université de Lille for its support. Thanks to Monique Gentric for administration management. We wish to thank the anonymous referees for their reviews that helped us improve our work. We also thank the Editor and editorial team of Chemical Geo$\log y$ for their time and energy.

\section{References}

Adriaens, R., Vandenberghe, N., Elsen, J., 2014. Natural Clay-Sized Glauconite in the Neogene Deposits of the Campine Basin (Belgium). Clays Clay Miner. 62, 35-52.

Amédro, F., 1994. Corrélations dans les craies cénomaniennes traversées par le tunnel sous la Manche. Bulletin de la Société Géologique de Normandie et des Amis du Museum du Havre, 81, 11-44.

Amédro, F. Robaszynski, F., 1999. The Cenomanian chalk of the Boulonnais. Comparison with the Aube (France) and Kent (United Kingdom). Géologie de la France, 2, 33-53.

Amorosi, A., 1995. Glaucony and sequence stratigraphy: a conceptual framework of distribution in siliciclastic sequences. Journal of Sedimentary Research, B65, 419-425.

Amorosi, A., Centineo, M.C., 2000. Anatomy of a Condensed Section: The Lower Cenomanian GlauconyRich Deposits of Cap Blanc-Nez (Boulonnais, Northern France). in Editor: C.R. Glenn, L. Prevot-Lucas, J. Lucas, Marine Authigenesis: From Global to Microbial, SEPM Society for Sedimentary Geology, 
Assale, F.Y.P., Akobe, A.C., Amani, E.M., Kplohi, Y.H.A., 2020. Evolution of glauconitization in Ivorian offshore basin: chemical and ultrastructural study of glauconites. Géologie de la France, $\mathrm{n}^{\circ}$ 2, 26-40.

Banerjee, S., Bansal, U., Pande, K., Meena, S.S., 2016a. Compositional variability of glauconites within the Upper Cretaceous Karai Shale Formation, Cauvery Basin, India: Implications for evaluation of stratigraphic condensation. Sedimentary Geology, 331, 12-29.

Banerjee, S. Jeevankumar, S., Eriksson, P.G., 2008. Mg-rich ferric illite in marine transgressive and highstand systems tracts: examples from the Paleoproterozoic Semri Group, central India. Precambrian Research, $162,212-226$.

Banerjee, S., Bansal, U., Thorat, U.V., 2016b. A review on palaeogeographic implications and temporal variation in glaucony composition. Journal of Palaeogeography, 5, 43-71.

Baronas, J.J., Hammond, D.E., McManus, J., Wheat, C.G., Siebert, C., 2017. A global Ge isotope budget. Geochimica et Cosmochimica Acta, 203, 265-283.

Bayliss, P., Syvitski, J.P.M., 1982. Clay diagenesis in recent marine fecal pellets. Geo- Marine Letters 2, 8388.

Bennett, W.W., Canfield, D.E., 2020. Redox-sensitive trace metals as paleoredox proxies: A review and analysis of data from modern sediments. Earth-Science Reviews, 204,103175.

Bohacs, K., 2005. Production, destruction, and dilution - the many paths to source-sock development. In: Harris, N. (ed.), The Deposition of Organic-Carbon-Rich Sediments: Models, Mechanisms, and Consequences. SEPM Special Publication No. 82, pp. 17-33.

Bout-Roumazeilles, V., Cortijo, E., Labeyrie, L., Debrabant, P., 1999. Clay-mineral evidence of nepheloid layer contribution to the Heinrich layers in the Northwest Atlantic. Palaeogeography, Palaeoclimatology, Palaeoecology, 146, 211-228.

Boyer, P. S., Guinness, E. A., Lynch-Blosse, M. A., Stolzman, R. A., 1977. Greensand fecal pellets from New Jersey. Journal of Sedimentary Research, 4, 267-280.

Breit, G.N., Wanty, R.B., 1991. Vanadium accumulation in carbonaceous rocks : a review of geochemical controls during deposition and diagenesis. Chem. Geol., 91, 83-97.

Burdige, D.J., 2006. Geochemistry of marine sediments. Princeton University Press, 609 p.

Carignan J., Hild, P., Morel J. \& Yeghicheyan D. (2004). - Routine analysis of trace elements in geochemical samples using flow injection and low-pressure on-line liquid chromatography coupled to ICP-MS: a study of geochemical references materials BR, DR-N, UB-N, AN-G and GH. - Geostand. Newslett., 25, 187-198.

Chamley, H., 1989. Clay Sedimentology. Springer, Berlin, 623 p.

Chamley, H., 2001. Clay Mineralogy. in: Encyclopedia of Ocean Sciences, pp. 462-471.

Deconinck, J.F., Holtzapplel, T., Robaszynski, F., Amédro, F., 1989. Données minéralogiques, géochimiques et biologiques comparées dans les craies cénomaniennes \& santoniennes du Boulonnais. Geobios, 11, 179-188.

Deconinck, J.F., Chamley, H., 1995. Diversity of smectite origins in Late Cretaceous sediments: example of chalks from Northern France. Clay Minerals, 30, 365-379. 
Dahl, T.W., Chappaz, A., Hoek, J., McKenzie, C.J., Svane, S., Canfield, D.E., 2016. Evidence of molybdenum association with particulate organic matter under sulfidic conditions. Geobiology, DOI: 10.1111/gbi.12220

El Albani, A. Meunier, A., Fursich, F., 2005. Unusual occurrence of glauconite in a shallow lagoonal environment (Lower Cretaceous, northern Aquitaine Basin, SW France). Terra Nova, 17, 537-544.

Franus, W., Franus, M., Latosińska, J., WówjIk, R., 2011.The use of spent glauconite in lightweight aggregate production. Boletín de la Sociedad Española de Cerámica y Vidrio, 50, 193-200.

Govindaraju, K., 1994. 1994 compilation of working values and sample description for 383 geostandards. Geostandards Newslett. 18, 1-158.

Guillermic, M., Lalonde, S.V., Hendry, K.R., Rouxel, O.J., 2017. The isotope composition of inorganic germanium in seawater and deep sea sponges. Geochimica et Cosmochimica Acta, 212, 99-118.

Gustafsson, J.P., 2019. Vanadium geochemistry in the biogeosphere -speciation, solid-solution interactions, and ecotoxicity. Applied Geochemistry, 102, 1-25.

Helz, G.R., Vorlicek,T.P., 2019. Precipitation of molybdenum from euxinic waters and the role of organic matter. Chem. Geol., 509, 178-193.

Hesselbo, S.P., Huggett, J., 2001. Glaucony in Ocean-Margin Sequence Stratigraphy (Oligocene-Pliocene, Offshore New Jersey, U.S.A.; ODP Leg 174A). Journal of Sedimentary Research 71, 599-607.

Huang, J.H., Huang, F., Evans, L., Glasauer, S., 2015. Vanadium: Global (bio)geochemistry. Chemical Geology, 417, 68-89.

Huggett, J, Adetunji, J, Longstaffe, F, Wray, D., 2017. Mineralogical and geochemical characterisation of warm-water, shallow-marine glaucony from the Tertiary of the London Basin. Clay Minerals, 52, 2550.

Huggett, J.M., 2021. Glauconites. in: Encyclopedia of Geology (Second Edition), pp. 334-340.

Jordan, R. W., Chamberlain, A.H.L., 1997. Biodiversity among haptophyte algae. Biodiversity \& Conservation, 6, 131-152.

Kapusta, Y., Steinitz, G., Akkerman, A., Sandler, A., Kotlarsky, P., Nagler, A., 1997. Monitoring the deficit of 39Ar in irradiated clay fractions and glauconites: Modeling and analytical procedure. Geo- chim. Cosmochim. Acta 61, 4671-4678.

Katz, B.J., 2005. Controlling factors on source rock development-A review of productivity, preservation, and sedimentation rate. In : Harris, N. (ed.), The Deposition of Organic-Carbon-Rich Sediments: Models, Mechanisms, and Consequences. SEPM Special Publication No. 82, pp..

Litchman, E., 2007. Resource Competition and the Ecological Success of Phytoplankton (chap.16). in: Paul G. Falkowski and Andrew H. Knoll (eds.), Evolution of Primary Producers in the Sea. Academic Press, pp. 351-375.

López-Quirós, A., Escutia, C., Sánchez-Navas, A. Nieto, F., Garcia-Casco, A., Martín-Algarra, A., Evangelinos, D., Salabarnada, A., 2019. Glaucony authigenesis, maturity and alteration in the Weddell Sea: An indicator of paleoenvironmental conditions before the onset of Antarctic glaciation. Sci Rep 9, 13580. 
López-Quirós, A., Sánchez-Navas, A., Nieto, F., Escutia, C., 2020. New insights into the nature of glauconite. American Mineralogist, 105, 674-686.

Meunier, A., El Albani, A., 2007. The glauconite-Fe-illite-Fe-smectite problem: a critical review. Terra Nova, 19, 95-104.

Meunier, J.D., 1994. The Composition and Origin of Vanadium-Rich Clay Minerals in Colorado Plateau Jurassic Sandstones. Clays Clay Miner. 42, 391-401.

Odin, G.S., Létolle, R., 1980. Glauconitization and phosphatization environments: a tentative comparison. In Marine Phosphorites. SEPM (Society for Sedimentary Geology), Special Publication, 29, pp. 227-237.

Odin, G.S., Matter, A., 1981. De glauconiarum origine. Sedimentology, 28, 611-641.

Robaszynski, F. Amédro, F., 1986. The Cretaceous of the Boulonnais (France) and a comparison with the Cretaceous of Kent (United Kingdom). Proc. Geol. Ass. 97 (2), 171-208.

Rouxel, O., Galy, A., Elderfield, H., 2006. Germanium isotopic variations in igneous rocks and marine sédiments. Geochimica Cosmochimica Acta, 70, 3387-3400.

Roy Choudhury, T., Banerjee, S., Khanolkar, S., Saraswati, P.K., Meena, S.S., 2021. Glauconite authigenesis during the onset of the Paleocene-Eocene Thermal Maximum: A case study from the Khuiala Formation in Jaisalmer Basin, India. Palaeogeography, Palaeoclimatology, Palaeoecology, 571, 110388.

Sageman, B.B., Murphy, A.E., Werne, J.P., Ver Straeten, C.A., Hollander, D.J., Lyons, T.W , 2003. A tale of shales: the relative roles of production, decomposition, and dilution in the accumulation of organic-rich strata, Middle-Upper Devonian, Appalachian basin. Chemical Geology, 195, 229-273.

Sutton, J., Ellwood, M. J., Maher, W. A., Croot, P. L., 2010. Oceanic distribution of inorganic germanium relative to silicon: germanium discrimination by diatoms, Global Biogeochem. Cycles, 24, GB2017, doi:10.1029/2009GB003689

Trentesaux, A., Recourt, P., Bout-Roumazeilles, V., Tribovillard, N., 2001. Carbonate grain-size distribution in hemipelagic sediments from a laser particle sizer. Journal of Sedimentary Research, 71, 858-862.

Tribovillard, N., Algeo, T.J., Lyons, T., Riboulleau, A., 2006. Trace metals as paleoredox and paleoproductivity proxies: an update. Chem. Geol., 232, 12-32.

Tribovillard, N., Bout-Roumazeilles, V., Riboulleau, A., Baudin, F., Danelian, T., Riquier, L., 2011. Transfer of germanium to marine sediments: insights from its accumulation in radiolarites and authigenic capture under reducing conditions. Some examples through geological ages. Chemical Geology, 282, 120-130.

Tribovillard, N., 2013. The Ge/Si ratio as a tool to recognize biogenic silica in chert. Comptes Rendus Geoscience, $345,160-165$.

Tribovillard, N., Hatem, H., Averbuch, O., Barbecot, F., Bout-Roumazeilles, V., Trentesaux, A., 2015. Iron availability as a dominant control on the primary composition and diagenetic overprint of organic-matter-rich rocks. Chemical Geology, 401, 67-82.

Tyson, R.V., 2005. The "productivity versus preservation" controversy: cause, flaws, and resolution. In : Harris, N. (ed.), The Deposition of Organic-Carbon-Rich Sediments: Models, Mechanisms, and Consequences. SEPM Special Publication No. 82, pp. 17-33. 
Tyson, R.V., 1995. Sedimentary organic matter: organic facies and palynofacies. Chapman \& Hall, London, $615 \mathrm{p}$.

Velde, B., 2014. Sediments, Diagenesis and Sedimentary Rocks. in: Treatise on Geochemistry (Second Edition), vol. 9, pp. 351-36.

Wanty, R.B. and Goldhaber, 1992. Thermodynamics and kinetics of reactions involving vanadium in natural systems : accumulation of vanadium in sedimentary rock. Geochim. Cosmochim. Acta, 56: 1471-183. 


\section{Figure caption}

Figure 1. Location of the Petit Blanc Nez part of the cliff, at the foot of which the samples were collected.

Figure 2. Pictures illustrating (A) the basal few meters of grey chalk containing glauconite, (B) the aspect of these glauconious chalks (the pocket knife gives the scale, (C) the darkest bed where glauconite amounts up to $44 \mathrm{wt} \%$ of the chalk, (D) glauconious chalk with cm-size phosphatic gravels and (F) the light-grey chalk where glauconite amounts to only $5 \mathrm{wt} \%$. The outcrop was wet after low tide, which accentuated the darkness of rock color.

Figure 3. Illustration of the four types of samples studied, with the indication of the weight proportion of glauconite in the rocks. Arrows: phosphatic debris.

Figure 4. SEM imaging of the carbonate-free and clay-free fraction of the samples : only glauconite pellets are observed (A), frequently bearing cracks (B).

Figure 5. Grain size distribution and mineralogical composition of the carbonate-free and clay-free fraction of the samples.

Table 1. SEM-EDS analyses of glauconite pellets.

Table 2. Elemental composition of selected major and trace elements) of the samples studied. L.D. stands for limit of detection, sw for seawater and s for sample. The bottom part of the table shows ratios between the samples studied and seawater composition.

Appendix Table S1. Complete results of the chemical analyses of the samples studied, carried out at the SARM facility of the CNRS (Vandoeuvre-les-Nancy, France). LOI stands for loss on ignition. 


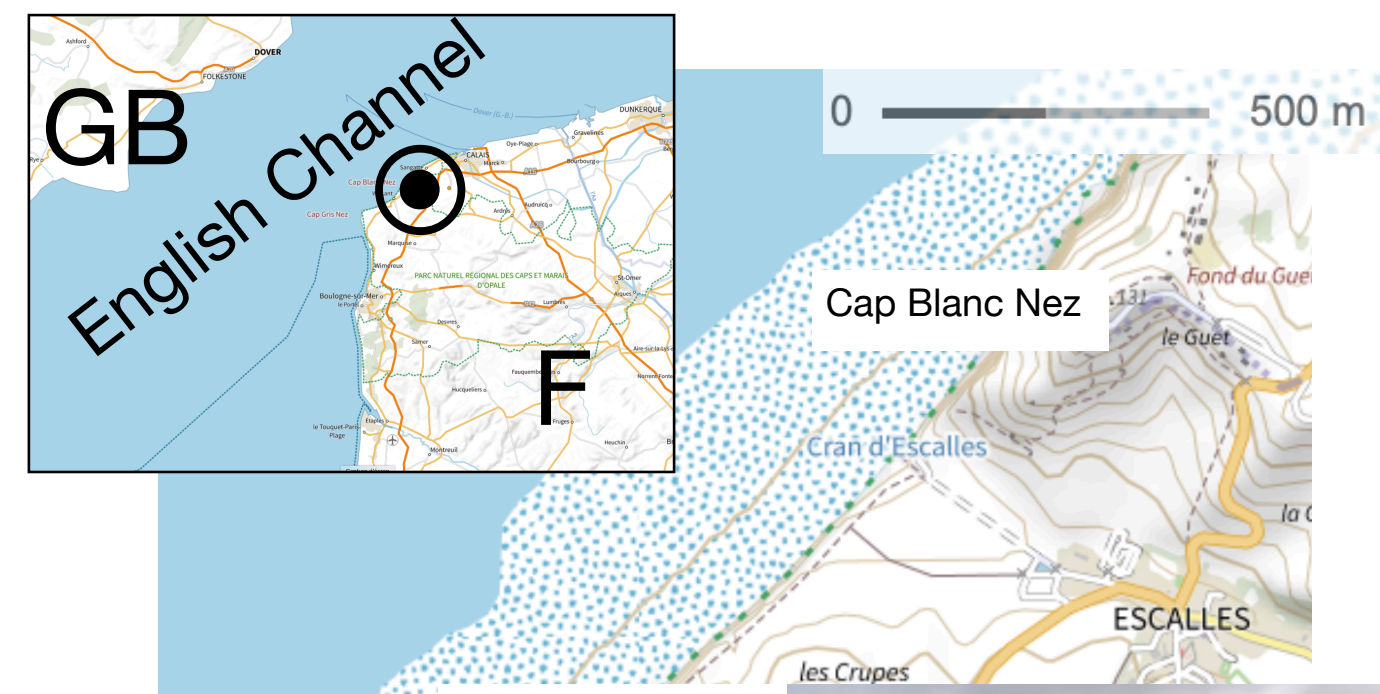

Le Petit Blanc Nez

es Crupes

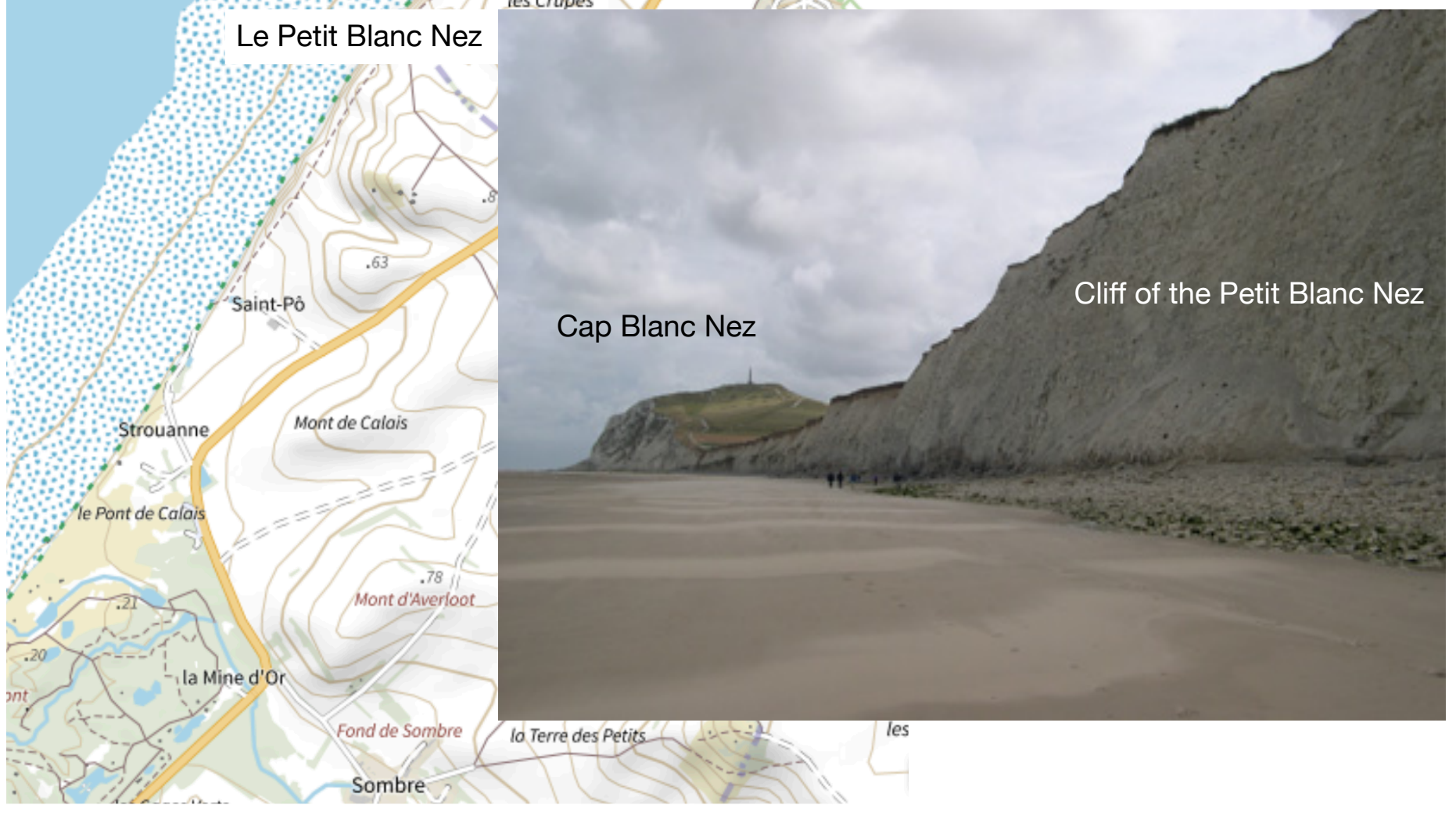

Figure

Cliff of the Petit Blanc Nez Sombre

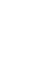



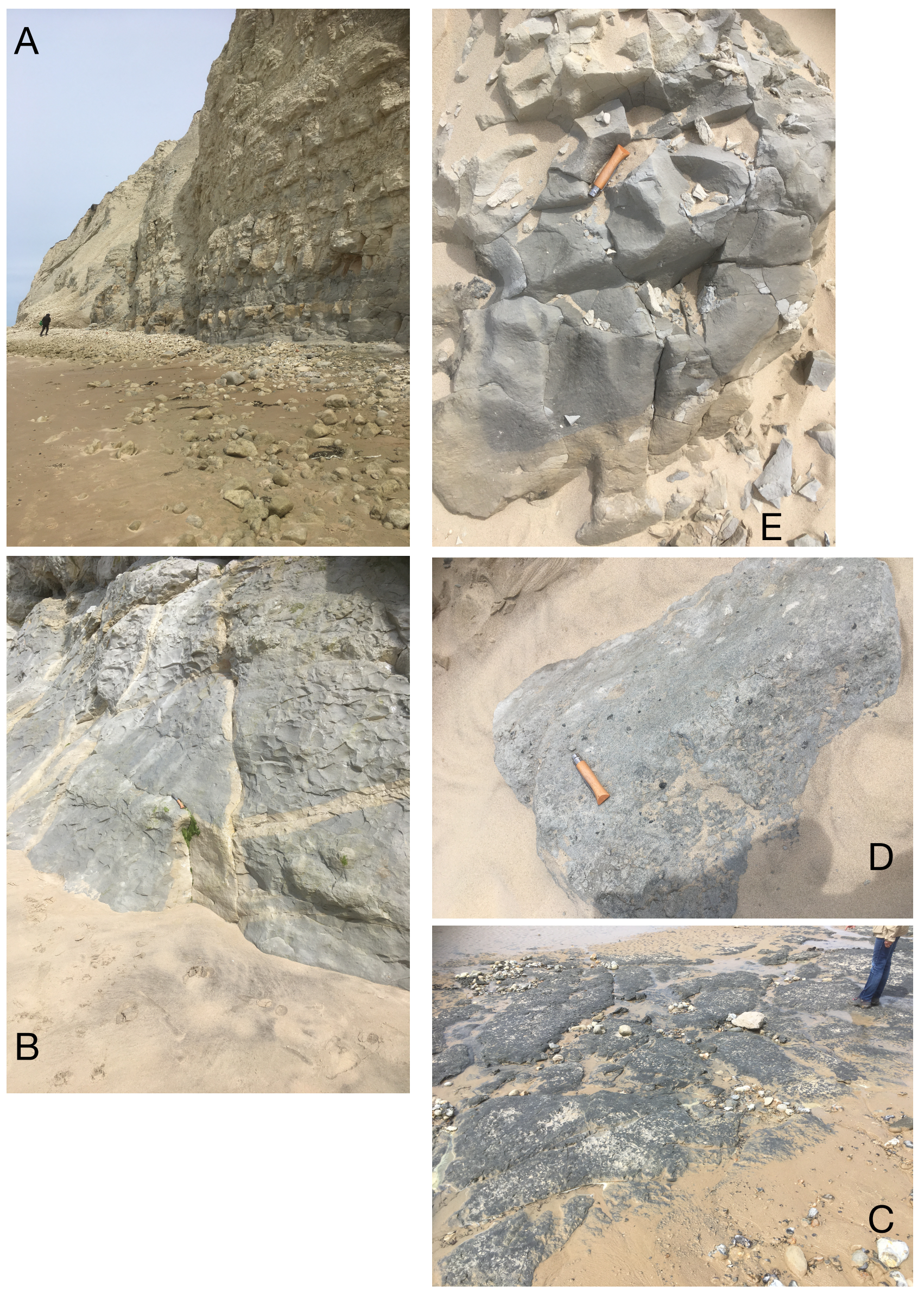


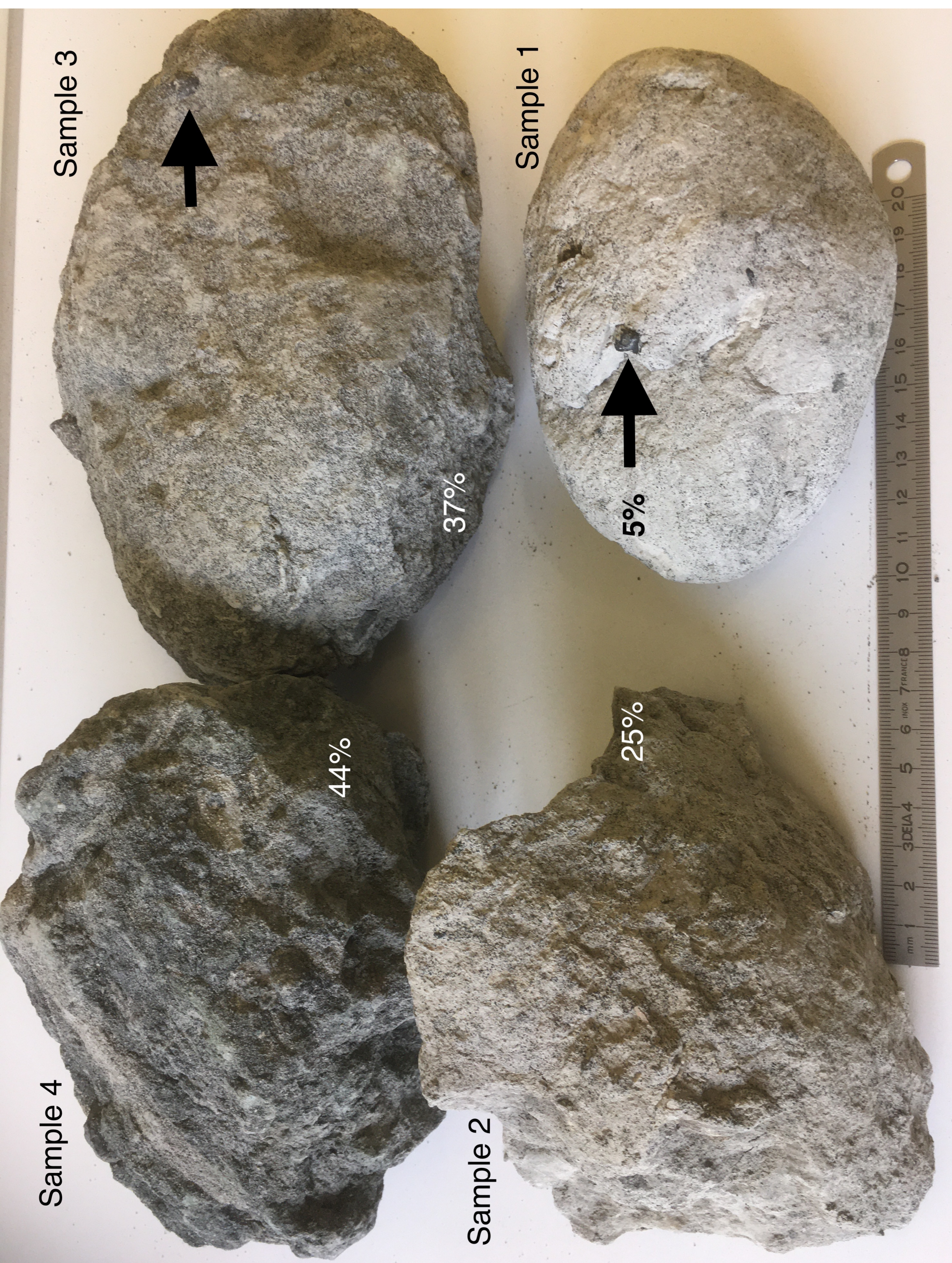



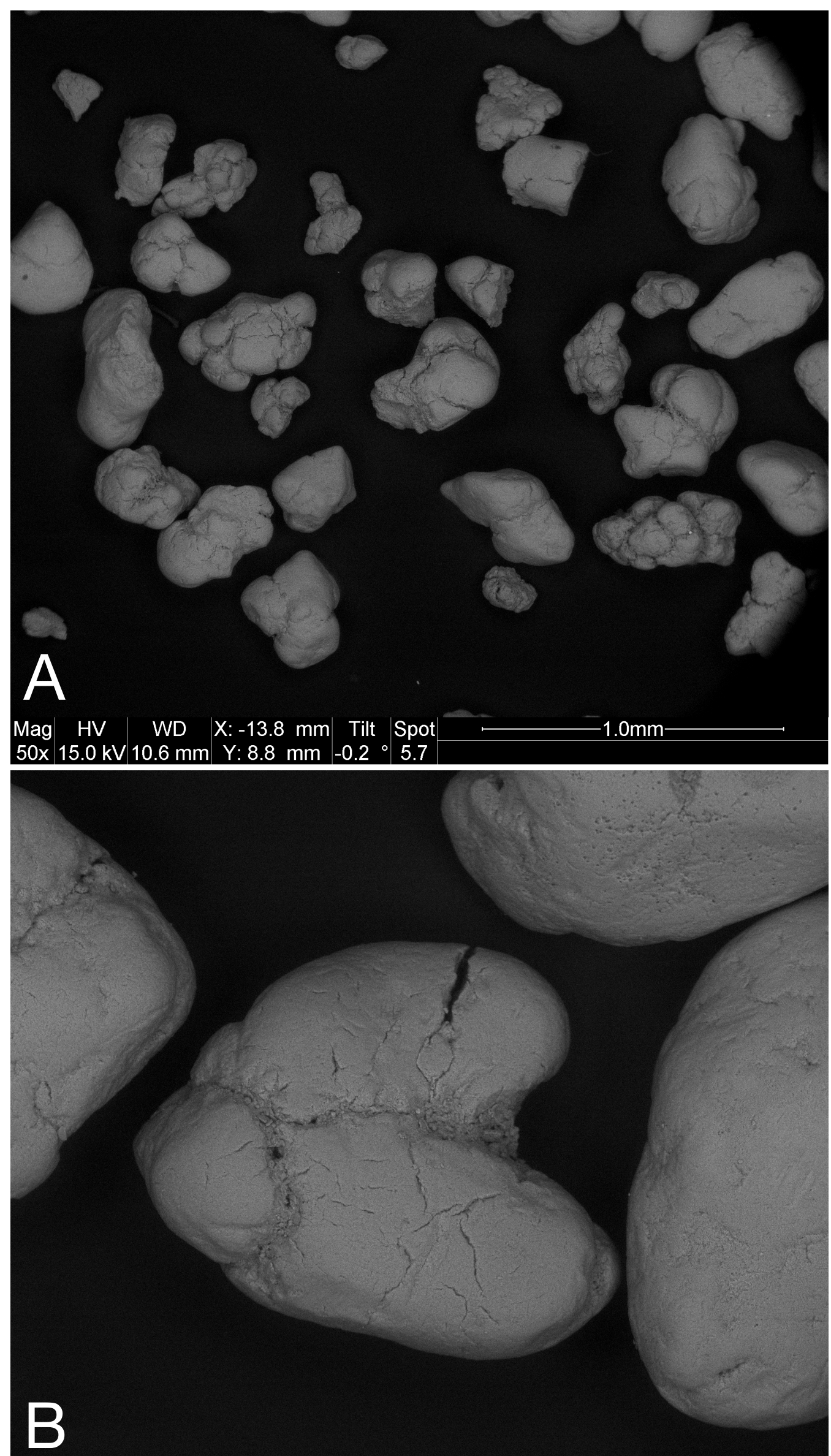

Mag HV $\quad$ WD $\quad$ X: $-20.3 \mathrm{~mm}$ Tilt $225 \times 15.0 \mathrm{kV} 10.6 \mathrm{~mm}$ Y: $7.5 \mathrm{~mm}-0.2^{\circ} 5.7$ 

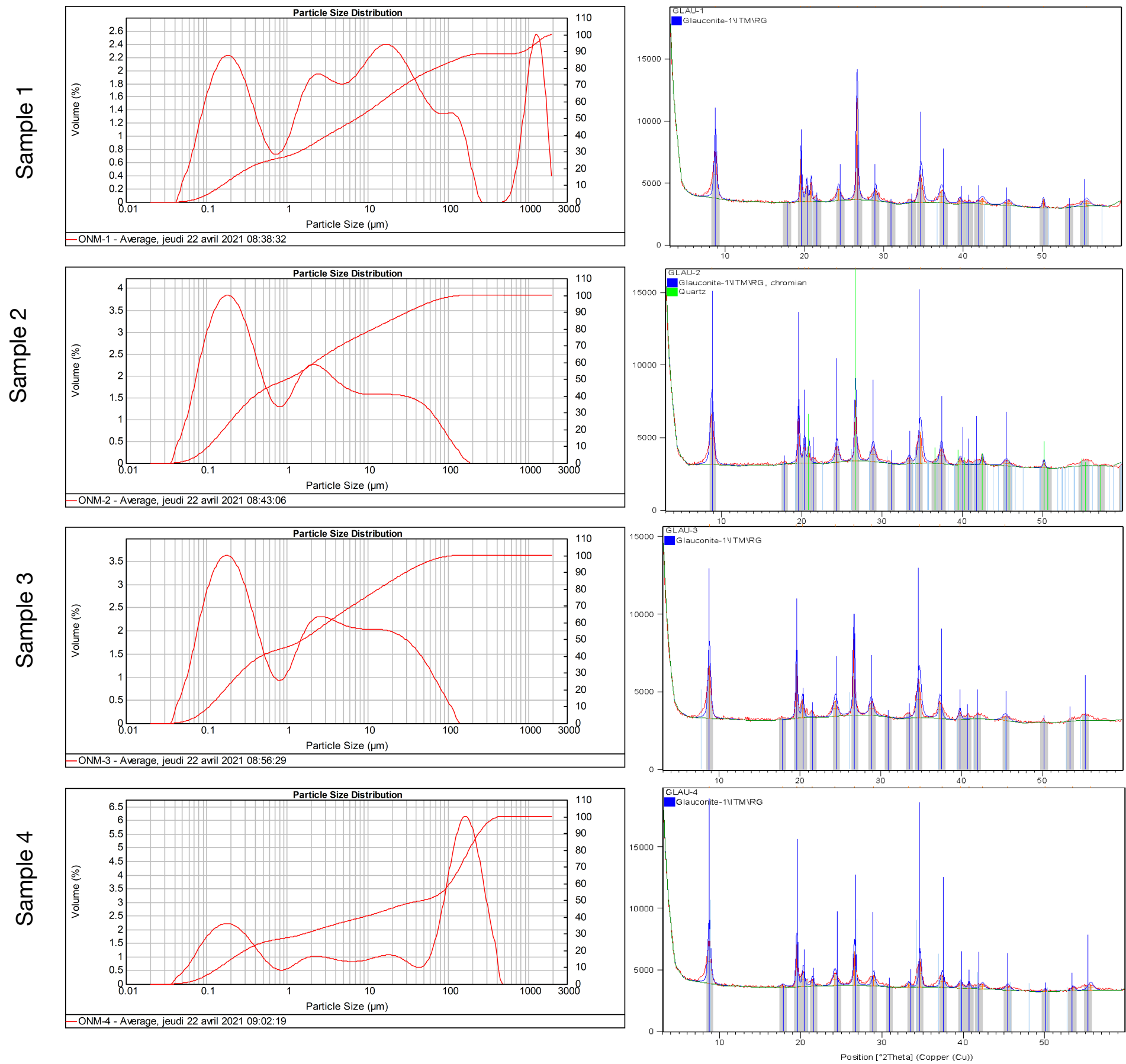
Tableau 1

\begin{tabular}{|c|c|c|c|c|c|}
\hline $\begin{array}{c}\text { Analytical } \\
\text { points }\end{array}$ & $\begin{array}{c}\text { Mg } \\
(\%)\end{array}$ & $\begin{array}{c}\text { Al } \\
(\%)\end{array}$ & Si (\%) & $\begin{array}{c}\text { K } \\
(\%)\end{array}$ & $\begin{array}{c}\text { Fe } \\
(\%)\end{array}$ \\
\hline 1 & 2.99 & 4.31 & 20.95 & 4.21 & 5.63 \\
\hline 2 & 2.49 & 4.42 & 20.40 & 4.96 & 6.16 \\
\hline 3 & 3.20 & 4.58 & 21.15 & 4.00 & 5.80 \\
\hline 4 & 2.31 & 3.30 & 20.92 & 4.69 & 6.94 \\
\hline 5 & 2.73 & 4.02 & 20.91 & 4.93 & 5.75 \\
\hline 6 & 1.98 & 3.47 & 20.59 & 5.87 & 6.71 \\
\hline 7 & 2.23 & 4.38 & 20.66 & 4.68 & 6.23 \\
\hline 8 & 2.11 & 3.99 & 20.82 & 4.69 & 6.52 \\
\hline
\end{tabular}




\begin{tabular}{|c|c|c|c|c|c|c|c|c|c|c|c|c|c|c|c|}
\hline Samples & $\begin{array}{c}\mathrm{SiO}_{2} \\
\%\end{array}$ & $\begin{array}{c}\mathrm{Al}_{2} \mathrm{O}_{3} \\
\%\end{array}$ & $\begin{array}{c}\mathrm{Fe}_{2} \mathrm{O}_{3} \\
\%\end{array}$ & $\begin{array}{c}\mathrm{MnO} \\
\%\end{array}$ & $\begin{array}{c}\mathrm{MgO} \\
\%\end{array}$ & $\begin{array}{c}\mathrm{CaO} \\
\%\end{array}$ & $\begin{array}{c}\mathrm{Na}_{2} \mathrm{O} \\
\%\end{array}$ & $\begin{array}{c}\mathrm{K}_{2} \mathrm{O} \\
\%\end{array}$ & $\begin{array}{c}\mathrm{TiO}_{2} \\
\%\end{array}$ & $\begin{array}{c}\mathrm{P}_{2} \mathrm{O}_{5} \\
\%\end{array}$ & $\begin{array}{l}\text { PF } \\
\%\end{array}$ & $\begin{array}{c}\text { Total } \\
\%\end{array}$ & $\begin{array}{c}\text { Mo } \\
\mu \mathrm{g} / \mathrm{g}\end{array}$ & $\begin{array}{c}U \\
\mu g / g\end{array}$ & $\begin{array}{c}\mathrm{V} \\
\mu \mathrm{g} / \mathrm{g}\end{array}$ \\
\hline 1 & 53.03 & 7.66 & 19.59 & < L.D. & 3.98 & 0.38 & 0.03 & 8.19 & 0.056 & < L.D. & 7.29 & 100.20 & < L.D. & 0.13 & 92.0 \\
\hline 2 & 52.45 & 7.95 & 19.46 & < L.D. & 4.18 & 0.31 & 0.03 & 8.39 & 0.044 & < L.D. & 7.39 & 100.20 & < L.D. & 0.09 & 92.4 \\
\hline 3 & 52.51 & 7.95 & 19.43 & < L.D. & 4.27 & 0.30 & 0.03 & 8.48 & 0.042 & < L.D. & 7.28 & 100.29 & $<$ L.D. & 0.10 & 94.5 \\
\hline 4 & 52.31 & 7.63 & 20.28 & < L.D. & 3.97 & 0.34 & 0.02 & 8.25 & 0.049 & < L.D. & 7.43 & 100.28 & < L.D. & 0.15 & 95.8 \\
\hline Samples & $\mathrm{Ge} / \mathrm{SiO}_{2}$ & $\mathrm{Ge} / \mathrm{SiO}_{2}$ & $\mathrm{Ge} / \mathrm{SiO}_{2}$ & U & U & V & V & & & & & & & & \\
\hline & Seawater & Samples & s/sw & sw & s/sw & sw & s/sw & & & & & & & & \\
\hline 1 & 0.020 & 0.09 & 4.6 & 3.2 & 0.04 & 2 & 46.00 & & & & & & & & \\
\hline 2 & & 0.09 & 4.6 & $\mu \mathrm{g} / \mathrm{g}$ & 0.03 & $\mu \mathrm{g} / \mathrm{g}$ & 46.2 & & & & & & & & \\
\hline 3 & & 0.10 & 5.1 & & 0.03 & & 47.3 & & & & & & & & \\
\hline 4 & & 0.10 & 4.9 & & 0.05 & & 47.9 & & & & & & & & \\
\hline
\end{tabular}


Ge

$\mu \mathrm{g} / \mathrm{g}$

4.80

4.75

5.25

5.07 
Click here to access/download

\section{Supplementary file Appendix Table S1.xlsx}

